\title{
Comparison of blunt and sharp needles for transforaminal epidural steroid injections
}

\author{
Transforaminal epidural steroid enjeksiyonları için künt ve \\ keskin uçlu iğnelerin karşılaştırılması
}

Ulaş ÖZCAN, ' Şükran ŞAHIN, ${ }^{2}$ Alp GURBET,2 Gürkan TÜRKER,' Mustafa ÖZGÜR,' Süreyya ÇELEBi'

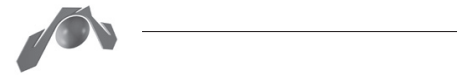

\section{Summary}

Objectives: The aim of this study was to compare the sharp and blunt needles in order to determine the incidence of complications during transforaminal anterior epidural steroid injections.

Methods: In this retrospective study, 185 cases that undergo transforaminal epidural steroid injection with sharp or blunt needles were evaluated between June 2004 and December 2008. Patients age, sex, diagnosis, needle type (sharp or blunt), volume of local anesthetic and steroid injected, complications (paresthesia, dural puncture, bleeding, paralysis, intravascular penetration, headache, local back pain, temporary motor loss in lower extremities) was recorded.

Results 3 cases in blunt needle group and 8 cases in sharp needle group showed paresthesia during the procedure. The difference was not found to be significant among the groups. Vascular penetration was observed in 2 cases in blunt and 13 cases in sharp needle group and the difference between groups was statistically significant $(\mathrm{p}<0.001)$. Dural puncture and headache incidence were not significant when the two groups are compared. The local back pain at the injection site had a higher incidence in the blunt needle group.

Conclusion: When using the blunt needles, vascular penetration and paresthesia were less during transforaminal epidural steroid injections. Therefore blunt needles seem to be more advantageous.

Key words: Blunt needle; sharp needle; transforaminal epidural steroid.

\section{Özet}

Amaçઃ Çalışmanın amact, transforaminal anterior epidural steroid enjeksiyonunda keskin ve künt uçlu iğnelerin komplikasyon insidansını karşılaştırmaktır.

Gereç ve Yöntem: Retrospektif çalışmada, Haziran 2004 ve Aralık 2008 taribleri arasında keskin veya künt uçlu iğne ile transforaminal epidural steroid enjeksiyonu uygulanan 185 olgu değerlendirildi. Hastalar yaş, cinsiyet, tanı, iğne tipi (keskin veya künt uçlu), lokal anestezik ve steroid miktarı, komplikasyonlar (parestezi, lomber ponksiyon, kanama, felç, damar içi penetrasyon, baş ağrısı, sırt ağrisı, alt ekstremitelerde geçici motor kayıp) kaydedildi.

Bulgular: Künt uçlu iğne grubunda 3 olguda, keskin uçlu iğne grubunda 8 olguda işlem sırasinda parestezi görüldü ancak gruplar arasinda anlaml fark bulunmadı. Vasküler penetrasyon künt uçlu grupta 2 olguda, keskin uçlu iğne grubunda 13 olguda gözlendi; gruplar arasında anlamlı fark bulundu $(p<0.001)$. İki grup karşılaştırıldığında dural ponksiyon ve baş ağrısı sıkliğı anlamlı bulunmadı. Enjeksiyon yerinde lokal bel ağrısı künt uçlu iğne grubunda daba yüksek bulundu.

Sonuç: Transforaminal epidural steroid enjeksiyonunda künt uçlu iğneler kullanildiğında vasküler penetrasyon ve parestezi daha az olmuştur. Bu nedenle künt uçlu iğne kullanımı daha avantajl görünmektedir.

Anahtar sözcükler: Künt uçlu iğne; keskin uçlu iğne; transforaminal epidural steroid.

Departments of ${ }^{1}$ Anesthesiology and Reanimation, ${ }^{2}$ Pain Clinic, Uludag University Faculty of Medicine, Bursa, Turkey

Uludağ Üniversitesi Tıp Fakültesi, 'Anesteziyoloji ve Reanimasyon Anabilim Dalı, ${ }^{2}$ Ağrı Kliniği, Bursa

Submitted (Başvuru tarihi) 29.11.2010～Accepted after revision (Düzeltme sonrası kabul tarihi) 01.03.2011

Correspondence (İletişim): Alp Gurbet M.D. Uludağ Üniversitesi Tıp Fakültesi, Algoloji Bilim Dalı, Bursa, Turkey

Tel: +90 - 224 - 2953147 e-mail (e-posta): agurbet@uludag.edu.tr 


\section{Introduction}

One of today's important medical and socioeconomic problems is lumbar pain and accompanying radicular symptoms. The rate of experiencing lumbar pain before the age of fifty is 80 to 85 percent. ${ }^{[1,2]}$ The most common causes are spinal stenosis and intervertebral disk herniation. The majority of the patients benefit from bed rest, oral drug intake, the use of lumbar corsets and physiotherapy; however, $10-15 \%$ of the patients may require surgical treatment. ${ }^{[2,3]}$ For medical treatment, salicylates, nonsteroidal anti-inflammatory drugs, tricyclic antidepressants and several muscle relaxants are used. One of the methods preferred for the patients not responding to medical treatment is epidural steroid injection. Epidural steroid injection is a widely used and efficacious method applied in the situations of nerve root compressions resulted from disk hernias, neuralgia, in the patients with spinal stenosis, scoliosis, spondylolisthesis or spondylosis, and for postlaminectomy pain of the patients. ${ }^{[4-6]}$

The mode of administration of steroid injection is the most important factor for the rate of success. ${ }^{[4,5]}$ Nowadays, it has been defined the transforaminal approach as an alternative to traditional caudal or inter laminar approaches, which allows the steroids to reach higher concentrations in target tissues. It is an efficacious and safe method, and besides an important advantage is to make injections into the anterior epiradicular space of a single segmental level. ${ }^{[4-6]}$ Transforaminal interventions possess certain risks such as intravascular injection, neural trauma, intraneural injection, subarachnoid injection. The intervention is performed under fluoroscopic control and usually with sharp needles.

In this study, we ascertained the sharp- and blunt spinal needles in terms of the complications (paresthesia during the procedure, dural puncture, intravascular injection and paralysis). The complications occurred were recorded.

\section{Materials and Method}

With the approval of the Faculty Ethics Committee (2008-15/73), 185 patient medical records, who were undergo transforaminal epidural steroid injections with blunt or sharp needles from 01 June 2004 to
31 December 2008, were analysed. Age, gender and diagnosis (spinal stenosis, lumbar disk injury, etc.) of the patients, level of the procedure, the needle type (Group S: Sharp, or Group B: Blunt), complications encountered (paresthesia, paralysis, intravascular injection, bleeding, dural puncture, headache occurred within the first 24 hours after procedure, local pain at the site of injection and transient leg weakness) were recorded. For TFESI we used $22 \mathrm{G}, 10 \mathrm{~cm}$, plain and blunt or sharp point needles for every procedure.

The analysis was done on SPSS for Windows 13.0 statistical pack software. The continuous variables were defined as the mean and standard deviation; categorical variables were defined as the number and percentage. The compatibility of the continuous variables to normal distribution was ascertained with Shapiro Wilk test; depending on the test results, independent double samples t-test from parametric tests or Mann-Whitney test from non-parametric tests was used for between-group comparisons of these variables. For between-group comparisons of categorical variables, Pearson's chi-square test and Fisher's exact chi-square test were used. Considering the dependent time periods of the score values, discrepancy scores of between-group comparisons and Mann-Whitney test was used for between-group comparisons. For within-group comparisons of the score values, Wilcoxon signed-rank test from nonparametric tests was used, in the study, $\mathrm{p}<0.05$ was regarded as statistically significant.

\section{Results}

There were no differences between the groups with regard to the demographic data (Table 1).

Presthesia developed during the procedure, 3 of the patients in Group B and 8 of the patients in Group $S$, however, this difference between two groups was found not statistically significant (Table 2).

Vascular penetration was observed in 15 patients performed through 3-arm fluoroscopy. Two of these events occurred with blunt needle and 13 cases with sharp needle. Comparing two needle types, it was found that with sharp needles, vascular penetration rate was statistically significantly higher compared to blunt needles $(\mathrm{p}<0.001)$, (Table 2$)$. 
Table 1. Demographic data

\begin{tabular}{lcc}
\hline & Group B & Group S \\
\hline Case number & 92 & 93 \\
Age & $53.2 \pm 5.3$ & $51.9 \pm 4.7$ \\
Sex (M/F) & $51 / 41$ & $57 / 36$ \\
\hline
\end{tabular}

Data were given as $\mathrm{n}$ or mean $\pm \mathrm{SD}$

Dural puncture occurred in four of our cases. One event occurred with blunt needle and three events with sharp needle. No difference was found between the groups $(\mathrm{p}<0.05)$.

During 24-hour follow up, two patients suffered from headache. It was observed that sharp needles were used in both interventions and they were the same cases to whom dural puncture was done during the procedure. Although dural puncture and headache were more frequent with sharp needle, comparison with blunt needle did not reveal any statistical significance.

Local (at the site of injection) pain was observed in 8 patients within the first 24 hours. Six of these events occurred with blunt needles and two of them with sharp needles. However, there were no statistically significant differences ( $\mathrm{p}>0.05)$.

\section{Discussion}

Steroid injection with transforaminal approach is preferred since it allows applying the drug directly into the anterior epidural area where the pathology is located. With this method, intra foraminal or extra foraminal application can be done. ${ }^{[7]}$ Since the risk of causing nerve injury through needle and/or drug is high, it is always needed to perform the interventions under scopic control. For the injections guided with contrast material and fluoroscopy, the rate of vascular penetration was reported to be $8.9 \%$ to $21.3 \%$. $^{[8]}$

In case of dural puncture, intrathecal analgesic/ corticosteroid injection may cause to compression, cauda equina syndrome, neural toxicity or local anesthetic toxicity because of increased volume of neural elements. ${ }^{[9]}$ The most common complication of dural puncture is to introduce the anesthetic substance into subdural space. This situation causes to subdural block. In the recent studies, the incidence of subdural injection was declared to be $0.82 \% .^{[10]}$ In our study, dural puncture occurred in $4(0.02 \%)$ of 185 patients; one of these events occurred with blunt needle, three events occurred during the interventions performed with sharp needles.

One of the complications that may happen after every epidural intervention is headache. It is known that it is caused by the leakage of CSF from the hole made by the needle perforating dural sheath and the decrease in CSF pressure. As a consequence of that, vasodilatation of cerebral vessels occurs. If the velocity of the leakage of CSF exceeds the CSF production capacity $(0.3 \mathrm{ml} / \mathrm{min})$, clinical symptoms manifest. This situation may occur following diagnostic lumbar puncture, myelography, spinal anesthesia. Typically, the headache is bilateral fron-

Table 2. Complications during or after procedure

\begin{tabular}{lccc}
\hline & $\begin{array}{c}\text { Group B } \\
(\mathbf{n = 9 2 )}\end{array}$ & $\begin{array}{c}\text { Group S } \\
(\mathbf{n = 9 3 )}\end{array}$ & $\mathbf{P}$ \\
\hline Paresthesia (-) & $89(96.7 \%)$ & $85(91.4 \%)$ & 0.125 \\
Paresthesia (+) & $3(3.3 \%)$ & $8(8.6 \%)$ & 0.221 \\
Vascular penetration (-) & $90(97.6 \%)$ & $80(86.7 \%)$ & 0.578 \\
Vascular penetration (+) & $2(2.4 \%)$ & $13(13.3 \%)$ & $0.0067^{*}$ \\
Dural puncture (-) & $91(98.9 \%)$ & $90(96.7 \%)$ & 0.998 \\
Dural puncture (+) & $1(1.1 \%)$ & $3(3.2 \%)$ & 0.623 \\
Headache (-) & $92(100 \%)$ & $91(97.8 \%)$ & 0.992 \\
Headache $(+)$ & 0 & $2(2.1 \%)$ & 0.498 \\
\hline
\end{tabular}

Data were given as $\mathrm{n}(\%)$. 
tal or retro-orbital, occipital and extending towards the nape. The pain involves neck and shoulders, is continuous and acute. Photophobia, nausea, tinnitus, hearing dysfunctions may accompany the pain. More severe cases may experience diplopia, cranial nerve damages. The most important characteristic of the pain is the association with position. The pain worsens while sitting and standing up, it resolves or alleviates while lying in supine position. If therapeutic protocols are not be applied, it lasts for months even for years. One of the most important determinative factors for the occurrence of headache is the type (blunt or sharp) and thickness of the needle. ${ }^{[1]}$ There are many studies proving that blunt-tipped needles reduce the incidence of headache. ${ }^{[12-15]}$ Westbrook et al. ${ }^{[15]}$ and Ready et al., ${ }^{[13]}$ in their distinct studies with blunt- and sharp needles having the same outer diameter, found that CSF loss was less with blunt needles. Kat1 et al., ${ }^{[16,17]}$ in a study with 60 patients, did not find any statistically significant difference between blunt and sharp needles with regard to headache. They observed headache in one patient from the group of blunt needle and in five patients from the group of sharp needle.

Evaluating the headache occurred within the first 24 hours after the intervention, we observed headache non of the patients with blunt needle and in 2 patients with sharp needle. This difference was not statistically significant. In the literature, there is no study showing the incidence of dural puncture by the type of needle in the transforaminal interventions. In the studies with spinal anesthesia practices comparing the blunt needles and sharp needles with smaller diameter, it was reported that blunt needles were less likely to cause to headache. ${ }^{[13-15]}$

Vascular penetration during invasive processes is a risk factor that may happen in all injection procedures. Potential complications of this situation are bleeding, hematoma formation, and intravascular drug injection. The likelihood of bleeding and hematoma formation is higher in the patients having coagulopathy, liver disease, or who are under anticoagulant therapy. Blood supply of medulla spinalis is ensured by segmental spinal arteries arisen from aorta. These arteries enter through intervertebral foramen at each spinal level. Segmental arteries give rise to three branches just before they enter the spi- nal canal. The branches are radicular arteries, anterior and posterior spinal arteries. Radicular artery extends throughout the nerve root and divides into anterior and posterior branches. The largest radicular artery is Adamkiewicz artery. The location and route of this artery should be known well. Usually, it lies at the left and between T9 and L1 in $80 \%$ of the cases.

Anterior blood flow of spinal cord is provided by a sole anterior spinal artery. Radicular feeding arteries are arisen from lumbar and intercostal arteries to help blood supply of anterior cord. The damages made to the vessels lying inwardly cannot be recognized on the standard fluoroscopic images. ${ }^{[9]}$ The incidence of epidural hematoma is approximately 1 in 150000 epidural. ${ }^{[18]}$ These epidural hematomas may cause to irreversible damage via compression of nerve root. ${ }^{[19]}$ The symptoms of nerve injury can be minimalized if they are diagnosed and treated within the first 24 hours after they manifest. Furman et al. reported the rate of intravascular injection to be $11.2 \% .{ }^{[19]}$ The rate of intravascular injection at $S 1$ level is $21.3 \%$ and it accounts for $8.1 \%$ of all intravascular injections. That risk is higher in ILESI because of the position of the needle. ${ }^{[20]}$ It is assumed that venous system does not have enough pressure to spontaneously push the blood back into the needle. However, during the injection of contrast material or drug, a positive pressure enough to distend these small vessels occurs and leads to intravascular injection. ${ }^{[19,21]}$ In the studies defining intravascular injection, it was not reported any complication after intravascular or intravenous contrast, steroid or local anesthetic injection. ${ }^{[20,21]}$ Machikanti et al., ${ }^{[22]}$ as a result of transforaminal epidural steroid injections at various levels in 100 patients, reported the rate of intravascular damage to be $16 \%$ in the lumbar region and $32 \%$ at the sacral level. Vascular penetration was observed in our 15 of 185 patients. Of these events, 2 events occurred with blunt-tipped needle and 13 events occurred in the interventions performed with sharp-tipped needles; the difference between these events was found to be statistically significant.

In a patient, the authors injected $1 \mathrm{ml}$ of iopamidol contrast into the region after a successful left L1 transforaminal intervention. Thereafter, they 
injected $5 \mathrm{ml}$ of bupivacaine $0.125 \%$ and $40 \mathrm{mg}$ of triamcinolone. They performed the intervention using 25-gauge and 22-gauge 3.5-inch sharp-tipped needles. The patient developed lower abdominal discomfort within 2 minutes and subsequently immobility of lower extremities for 1 minute. It was reported that the same neurological picture of the patient sustained even on the control after 4 years and the patient still had chronic pain. ${ }^{[23]}$ By today, only four cases of spinal cord injury due to intraarterial injection because of abnormal anatomy of Adamkiewicz artery were reported. ${ }^{[23,24]}$ None of our patients developed paralysis.

In conclusion, there seems to be no difference between blunt and sharp needles in the practices of transforaminal steroid injection in terms of the occurrence of dural puncture, headache, and local pain during the intervention. However, fewer numbers of the events of vascular penetration and paresthesia make the blunt needles more advantageous.

\section{References}

1. Karaeminoğulları O, Aydınlı U. Dejeneratif lomber spinal stenoz. TOTBiD Dergisi 2004;3:3-4.

2. Heliövaara $M$, Knekt $P$, Aromaa $A$. Incidence and risk factors of herniated lumbar intervertebral disc or sciatica leading to hospitalization. J Chronic Dis 1987;40(3):251-8.

3. Saal JA, Saal JS. Nonoperative treatment of herniated lumbar intervertebral disc with radiculopathy. An outcome study. Spine (Phila Pa 1976) 1989;14(4):431-7.

4. Vad VB, Bhat AL, Lutz GE, Cammisa F. Transforaminal epidural steroid injections in lumbosacral radiculopathy: a prospective randomized study. Spine (Phila Pa 1976) 2002;27(1):116.

5. Papagelopoulos PJ, Petrou HG, Triantafyllidis PG, Vlamis JA, Psomas-Pasalis M, Korres DS, Treatment of lumbosacral radicular pain with epidural steroid injections. Orthopedics 2001;24(2):145-9.

6. Fontaine R, Tomasella M, Martin D, Lacroix J, Lecart MP, Libbrecht $\mathrm{D}$, et al. Indications for epidural steroids in back pain and in radiculopathy. Rev Med Liege 2004;59(10):557-64. [Abstract]

7. Bonetti $M$, Fontana A, Cotticelli B, Volta GD, Guindani $M$, Leonardi M. Intraforaminal $\mathrm{O}(2)-\mathrm{O}(3)$ versus periradicular steroidal infiltrations in lower back pain: randomized controlled study. AJNR Am J Neuroradiol 2005;26(5):996-1000.

8. Smuck M, Fuller BJ, Yoder B, Huerta J. Incidence of simultaneous epidural and vascular injection during lumbosacral transforaminal epidural injections. Spine J 2007;7(1):79-82.

9. Goodman BS, Bayazitoglu M, Mallempati S, Noble BR, Geffen JF. Dural puncture and subdural injection: a complication of lumbar transforaminal epidural injections. Pain Physician 2007;10(5):697-705.

10. Lehmann LJ, Pallares VS. Subdural injection of a local anesthetic with steroids: complication of epidural anesthesia. South Med J 1995;88(4):467-9.

11. Tarkkila PJ, Heine H, Tervo RR. Comparison of Sprotte and Quincke needles with respect to post dural puncture headache and backache. Reg Anesth 1992;17(5):283-7.

12. Lambert DH, Hurley RJ, Hertwig L, Datta S. Role of needle gauge and tip configuration in the production of lumbar puncture headache. Reg Anesth 1997;22(1):66-72.

13. Ready LB, Cuplin S, Haschke RH, Nessly M. Spinal needle determinants of rate of transdural fluid leak. Anesth Analg 1989;69(4):457-60.

14. Vallejo MC, Mandell GL, Sabo DP, Ramanathan S. Postdural puncture headache: a randomized comparison of five spinal needles in obstetric patients. Anesth Analg 2000;91(4):91620.

15. Westbrook JL, Uncles DR, Sitzman BT, Carrie LE. Comparison of the force required for dural puncture with different spinal needles and subsequent leakage of cerebrospinal fluid. Anesth Analg 1994;79(4):769-72.

16. Katı I, DemirelCB. Iğnetipinin spinal anestezi komplikasyonları üzerine etkileri. Van Tıp Dergisi 2002;9(2):47-51.

17. Katı I, Demirel CB, Abbasov ÜH, Silay E, Coskuner İ, Tokmak Y. Iğne tipinin spinal anestezi komplikasyonları üzerine etkileri. Van Tıp Dergisi 2002;9(2):47-51.

18. Horlocker TT, Wedel DJ, Benzon H, Brown DL, Enneking FK, Heit JA, et al. Regional anesthesia in the anticoagulated patient: defining the risks (the second ASRA Consensus Conference on Neuraxial Anesthesia and Anticoagulation). Reg Anesth Pain Med 2003;28(3):172-97.

19. Nelson J. Letter to the editor Re: Blunt needles. International Spine Intervention Society Newsletter 2006;5:58-60.

21. Sullivan WJ, Willick SE, Chira-Adisai W, Zuhosky J, Tyburski $M$, Dreyfuss $P$, et al. Incidence of intravascular uptake in lumbar spinal injection procedures. Spine (Phila Pa 1976) 2000;25(4):481-6.

20. Akins EW, Hawkins IF Jr, Mladinich C, Tupler R, Siragusa RJ, Pry R. The blunt needle: a new percutaneous access device. AJR Am J Roentgenol 1989;152(1):181-2.

22. Manchikanti L, Cash KA, Pampati V, Damron KS, McManus CD. Evaluation of lumbar transforaminal epidural injections with needle placement and contrast flow patterns: a prospective, descriptive report. Pain Physician 2004;7(2):217-23.

23. Huntoon MA, Martin DP. Paralysis after transforaminal epidural injection and previous spinal surgery. Reg Anesth Pain Med 2004;29(5):494-5.

24. Houten JK, Errico TJ. Paraplegia after lumbosacral nerve root block: report of three cases. Spine J 2002;2(1):70-5. 